\title{
Prioritize factors affecting the high-tech industry investment in East Azerbaijan province using prioritization techniques VIKOR
}

\author{
Mahsa Behrouz ${ }^{32}$, Nasser fegh-hi farahmand ${ }^{33}$
}

\begin{abstract}
This study aimed to prioritize investment factors affecting the high-tech industry in the East Azerbaijan province, using the technique of prioritization, fuzzy VIKOR. This study is the kind of researches is descriptive- survey and placed in the category applied research whose results can be used to improve the high-tech industry investment in East Azerbaijan province. In this study Research population, including the administrators and industrialists are the province of high-tech equipment and technology. According to the information received by the community of 10 companies and organizations manufacturing. When population size is limited (10 units) and qualitative variables, so all population used as a sample. According to the results management criterion most significant role in attracting investment in high-tech industries, and measures affecting investment profit in second place in the industry is high-tech and to the next level, with measures of political stability, opportunity, risk and cost.
\end{abstract}

KEY WORDS: High-tech Industry, Investment, Opportunity, Cost, VIKOR Fuzzy Techniques

JEL: E52, D23

UDC: $336.581: 338.45(479.24)$

005.322:316.46

COBISS.SR-ID 238315276

\footnotetext{
${ }^{32}$ Department of Management, Tabriz branch, Islamic Azad University, Tabriz, Iran,email:mahsa.behrouz@gmail.com

${ }^{33}$ Department of Management, Tabriz Branch, Islamic Azad University, Tabriz, Iran,e-mail: farahmand@iaut.ac.ir
} 


\section{INTRODUCTION}

In the world of liberalization and globalization, in the case of economic growth and development can continue that countries can develop higher value-added activities and newer and to produce goods and services that would maintain their position in the competitive market. In this investment as an effective tool in production can play an important role in helping firms (Carbaugh, 2002). Today it's no secret that indispensable for economic growth and development in all human societies, whether developed or developing, Investments to increase the quantity and quality of the product and create new job opportunities and thus improve public welfare (Sitkin, Weingart, 2005). Obviously, there is a flourishing industry for pure and definite policy, But always need to adopt effective strategies is to review investment and pushing it toward the optimal policy and it would not be possible unless the targeted studies and research periodicals, new and effective solutions to be put before the owners and activists industry (Satya, 2012). In this regard, the information collection and provision of special indicators can be effectively used to adopt effective solutions. In other words, economic indicators last survey that enables future growth (Yong, 2006). Over the past years, harvest technology professionals, has been picked up hardware and in most cases, managers of the industry to achieve the advanced technology as the only way to buy newer machines and Purchased with the latest models of machines and equipment tried to stay back behind the rapid technology (Agrawal, 2008).

Today, the notion of science in the field of industry has been largely transformed and Managers know that buying hardware, although sometimes necessary in order to achieve superior technology, but no-doubt is not enough and Elements such as human resources or technical knowledge is essential for optimal performance of each hardware platforms (Banga, 2009). Referred to as high-tech technologies that have certain characteristics. First, the development of high-speed technologies (Ertuğrul, Karakaşoğlu, 2006). Sometimes the life of these technologies is less than a year, whereas in traditional technologies, life expectancy more than 10 years. Second, the role of human resources is higher than the hardware (Frawsen, Henrick, 2004). This means that if we measure the extra value that is created, the share of hightech human resources in the creation of added value, much more bold. In addition, the factors that cause this effect, the practical capabilities of manpower nor the experience or physical effort for him. In other words, the role of science in hitech over the role of experience. Third, the added value of technology in the production of the final product rather than other factors (such as raw materials, energy, etc.) is very high (Carbaugh, 2010). Economic development aspirations of all developing countries and countries choose different means to achieve this (Kahraman et al., 2007). Capital One factor is the fact that the main factors in the development of countries and other economic variables such as employment, GDP, supply of goods and services and this factor affected directly (Aswicahyono, 2011). Countries to design mechanisms are used by some countries to attract more capital from internal and external sources. Among the mechanisms used by some countries to achieve this objective is to invest in high-tech industries, which if successful could be technology transfer, employment, human resource development and exports also be followed (Robert, Hong, 2010). Ultimately enhance current investment objective is capital appreciation, which in and of itself in this process, the next time, efficiency, risk factors, cash flow patterns, building capital, capital costs, etc. will be discussed. So to achieve this goal, we must follow the fundamental thinking and in the meantime, according to the theory of investment is required (Lutz, Turrini, 2006). Willingness to invest in high-tech industries, in itself, not a means of attracting investment, but also in terms of attracting investment in this industry are many factors involved in this study factors will be identified and Prioritization. Identification of investment opportunities with high efficiency and prioritization of the matter is that today the main focus in the allocation of investment resources 
with extended features. Prioritize investments in addition to providing the possibility of allocating resources, the time and costs of pre-investment, reduce the project study. Prioritize investments, although activity is common, but is certain complexities. The complexity of quantitative and qualitative evaluation of the effects of multiple criteria and multiple decision makers involved in this process stems (Kaufmann et al., 2009). With regard to the issues raised in this study using the opinions of experts and professors studied management and economics to identify the main criteria and then use the following investment criteria (cultural, governmental, legal, administrative, regional, economic and investment Mark) shall pay to the ranking criteria (risk, cost, time, profit, management and political stability) affecting investment in high-tech industries. The aim of this study is to prioritize investment factors affecting the high-tech industry in East Azerbaijan province using prioritization techniques VIKOR phase.

\section{RESEARCH METHOD}

In this study, the independent variables are the main criteria (risk, cost, time, profit, management and political stability) and sub-criteria (cultural, governmental, legal, administrative, regional, economic and investment) is. The dependent variable is investment in high-tech industries. 


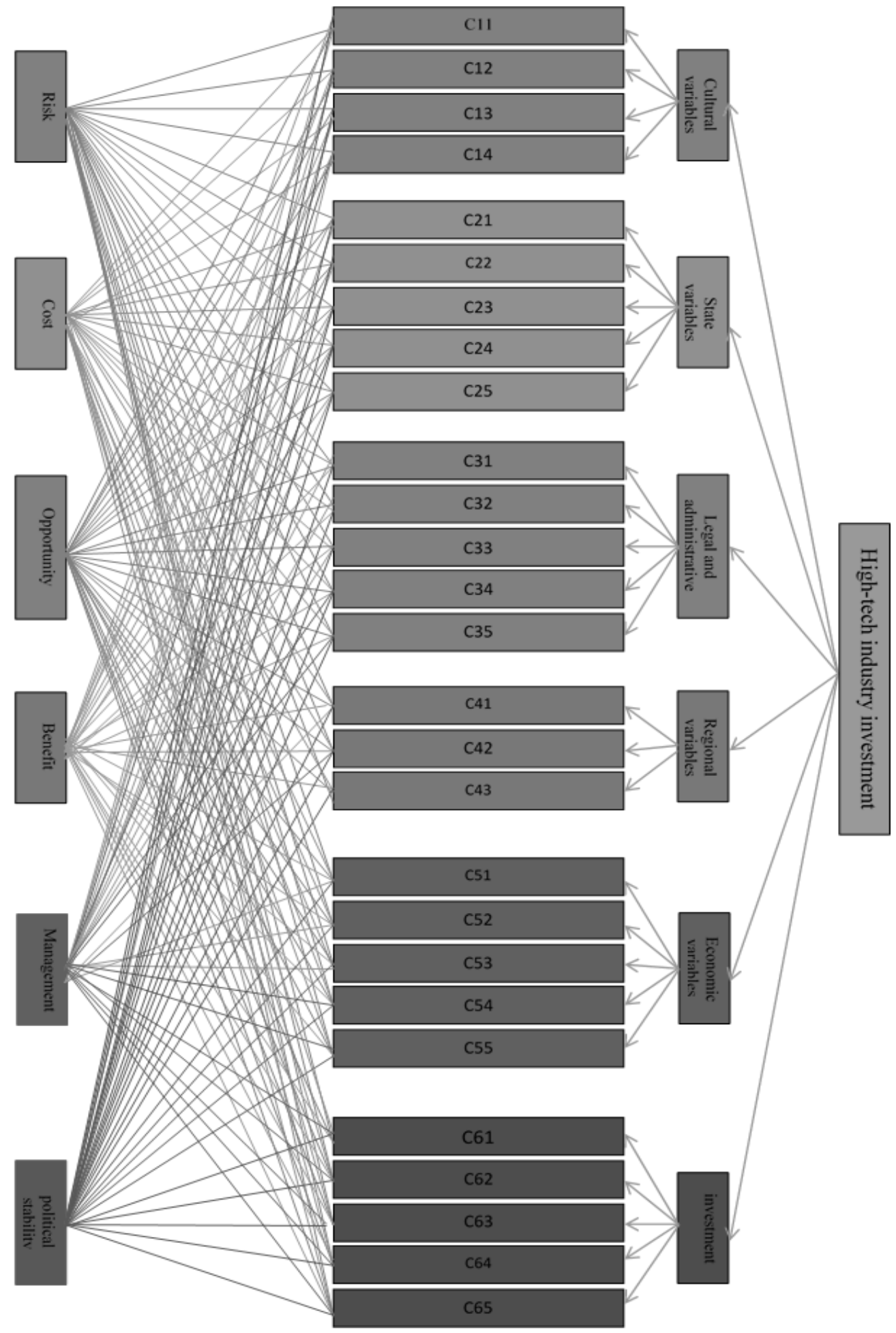

Figure 1: Conceptual Model Research 
The study was a descriptive study - a survey of sight is practical purpose. The population in this study, including managers and owners of large industries in East Azarbaijan Province single-use industries as they are. According to information received study population consisted of approximately 10 organizations and companies are manufacturing. Such as population size was limited (10 units) and qualitative variables, so use all the population as the sample size. This study of the implementation of the first half and at the end of 2014 beginning of 2014 come to an end. Data analysis was performed using fuzzy techniques VIKOR.

\section{RESEARCH FINDINGS}

In this section, after identifying major and minor criteria by professors and experts (according to research conceptual model) using'll Payment sub-criteria ranking of the main criteria affecting investment in high-tech industries using fuzzy VIKOR. To determine the weight of importance of the criteria used by the decision-maker $10=\mathrm{k}$ through linguistic variables. Experts were asked the following criteria on the basis of 28 criteria in six linguistic variables compare. Table 1, criteria and sub-criteria used shows.

Table 1: Evaluation criteria for investment in high-tech industries

\begin{tabular}{|c|c|c|c|}
\hline \multicolumn{2}{|c|}{ criteria } & \multicolumn{2}{|r|}{ sub criteria } \\
\hline \multirow{4}{*}{$\mathrm{C} 1$} & \multirow{4}{*}{ 的总 } & $\mathrm{C} 11$ & Appropriate behavior related institutions and organizations \\
\hline & & $\mathrm{C} 12$ & Suitable culture of work and production \\
\hline & & $\mathrm{C} 13$ & Investment worth thinking \\
\hline & & $\mathrm{C} 14$ & Ethnic and religious tensions \\
\hline \multirow{5}{*}{$\mathrm{C} 2$} & \multirow{5}{*}{ 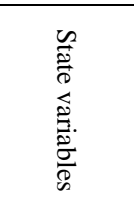 } & $\mathrm{C} 21$ & Government policies and policy \\
\hline & & $\mathrm{C} 22$ & The relative stability in rates and prices \\
\hline & & $\mathrm{C} 23$ & Transparency in the production \\
\hline & & $\mathrm{C} 24$ & Transparency of information and statistics \\
\hline & & $\mathrm{C} 25$ & Lack of discrimination between the productive sectors \\
\hline \multirow{5}{*}{$\mathrm{C} 3$} & \multirow{5}{*}{ 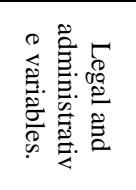 } & $\mathrm{C} 31$ & Stability in the rules and regulations \\
\hline & & $\mathrm{C} 32$ & There are mental and simplified administration \\
\hline & & $\mathrm{C} 33$ & Flexibility rules \\
\hline & & $\mathrm{C} 34$ & Coherent relationship between science centers \\
\hline & & $\mathrm{C} 35$ & Reduce holidays and vacation \\
\hline \multirow{3}{*}{$\mathrm{C} 4$} & \multirow{3}{*}{ 宓帝. } & $\mathrm{C} 41$ & There are infrastructure facilities like roads, railways, airports and... \\
\hline & & $\mathrm{C} 42$ & There are efficient and capable management \\
\hline & & $\mathrm{C} 43$ & There is a regional strategy to guide investors \\
\hline \multirow{5}{*}{$\mathrm{C} 5$} & \multirow{5}{*}{ 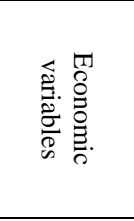 } & $\mathrm{C} 51$ & Proximity to large markets \\
\hline & & C52 & Tax cuts and financial risk \\
\hline & & C53 & Labor productivity \\
\hline & & C54 & Inflation \\
\hline & & C55 & Exchange rate fluctuations \\
\hline \multirow{5}{*}{ C6 } & \multirow{5}{*}{ 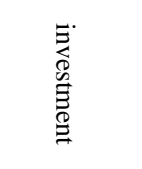 } & C61 & Economic variables \\
\hline & & C62 & State variables \\
\hline & & C63 & Legal variables \\
\hline & & C64 & Cultural variables \\
\hline & & C65 & Regional variables \\
\hline
\end{tabular}

In the second phase of the 10 experts were asked to compare the 6 criteria based on 28 subcriteria. In the third stage of the decision-making matrix is combined 10 experts. Using the following formula and 10 expert opinions obtained by combining matrices criteria - the individual decision maker and decision maker - Options - criteria. 


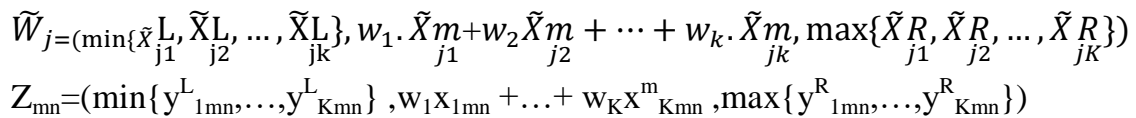

So that wj, weight fuzzy important criteria for MS j. In the fourth stage comes before the fuzzy values based on the average value of defuzzification, fuzzy-adjusted and absolute numbers. These numbers were calculated using Excel.

Table 2: Fuzzy de-composition of the matrix of criteria - the individual decision maker and decision maker - Options - Criteria

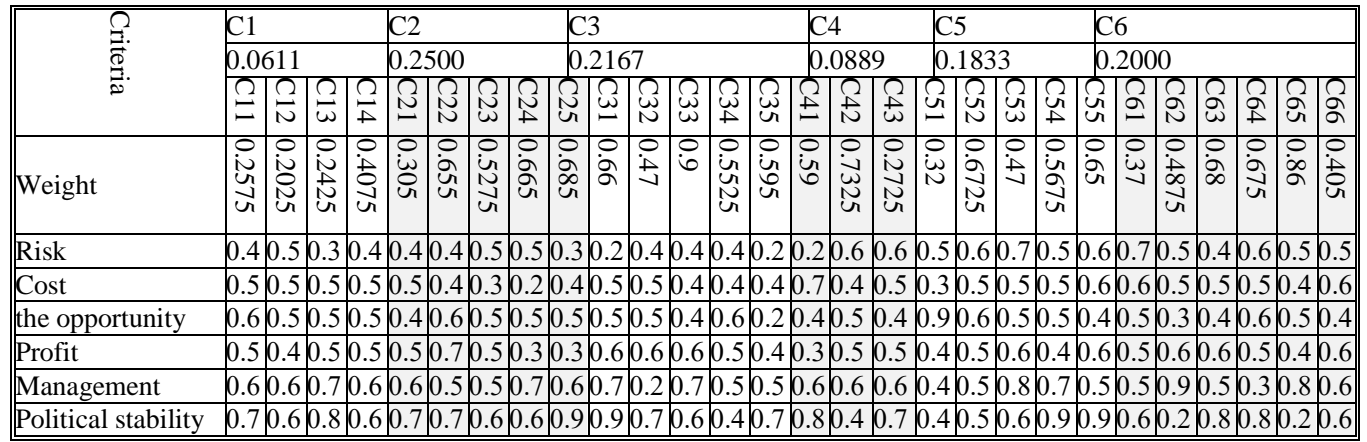

In the fifth round, ideal and anti-ideal values for each criterion and the results in Table 3 below.

Table 3:Ideal and anti-ideal values criteria

\begin{tabular}{|c|c|c|c|c|c|c|c|c|c|c|c|c|c|c|c|c|c|c|c|c|c|c|c|c|c|c|c|c|}
\hline $\begin{array}{l}\text { sub } \\
\text { crit } \\
\text { eri } \\
\text { e }\end{array}$ & $\overline{\tilde{u}}$ & $\tilde{u}$ & $\vec{U}$ & $\stackrel{ \pm}{U}$ & $\overline{\widetilde{U}}$ & ปี & తి & ঠ̃ & ป̂̃ & $\overline{\tilde{\vartheta}}$ & $\tilde{ల ే ~}$ & $\tilde{\delta}$ & 记 & $\tilde{\mho}$ & $\bar{J}$ & J & 尊 & $\bar{v}$ & $\tilde{0}$ & $\tilde{\tilde{z}}$ & 范 & है & $\overline{0}$ & ర্ & $\hat{\theta}$ & t & 8 & ن \\
\hline$f+$ & $\tilde{o}$ & $\stackrel{\circ}{\circ}$ & $\stackrel{\infty}{\circ}$ & $\stackrel{\circ}{\circ}$ & $\hat{o}$ & $\ddot{o}$ & $\stackrel{0}{\circ}$ & $\hat{o}$ & $\hat{o}$ & gे & $\tilde{o}$ & $\hat{o}$ & $\stackrel{\circ}{\circ}$ & $\tilde{o}$ & $\stackrel{\infty}{\circ}$ & $\stackrel{\circ}{\circ}$ & $\hat{\circ}$ & $\stackrel{8}{0}$ & $\stackrel{\circ}{\circ}$ & 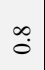 & oे & $\stackrel{\circ}{0}$ & $\hat{\circ}$ & o. & $\stackrel{\infty}{\circ}$ & $\stackrel{\infty}{\circ}$ & $\stackrel{\infty}{0}$ & $\stackrel{\circ}{\circ}$ \\
\hline$f-$ & $\stackrel{t}{\circ}$ & $\stackrel{t}{0}$ & ?3. & t. & $\stackrel{t}{0}$ & $\stackrel{+}{0}$ & 3 & กֶ. & 3 & ชี & ชี & $\stackrel{t}{0}$ & $\stackrel{t}{\circ}$ & תุ & กี & $\stackrel{t}{0}$ & $\stackrel{t}{0}$ & $\tilde{o}$ & $?$ & ? & $\stackrel{t}{0}$ & $\stackrel{t}{0}$ & 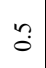 & $\tilde{O}$ & $\stackrel{t}{\circ}$ & 3 & ฮี & $\stackrel{t}{0}$ \\
\hline
\end{tabular}

According to the table above for each sub-criterion largest number as the ideal and is selected the smallest number of sub-criteria, sub-criteria as the amount of anti ideal. The next step is to calculate the size of the utility ( $\mathrm{Si}$ ) and the size of the effect (Ri) of each option. The following table shows the result

$$
\begin{aligned}
& \mathrm{S}_{\mathrm{i}=}=\sum_{\mathrm{j}=1}^{\mathrm{m}}\left\{\frac{\mathrm{w}_{\mathrm{j}\left(\mathrm{f}_{\mathrm{i}}^{+}-\mathrm{f}_{\mathrm{ij}}\right)}}{\mathrm{f}_{\mathrm{i}}^{+}-\mathrm{f}_{\mathrm{j}}-}\right\} \\
& R_{i}=\max \left\{\frac{{ }_{j\left(f_{i}^{+}-f_{i j}\right)}}{f_{i}^{+}-f_{j^{-}}}\right\}
\end{aligned}
$$

Table 4: The size utility and the size of the effect of each option

\begin{tabular}{|c|c|c|}
\hline Options & $\mathrm{Si}$ & $\mathrm{Ri}$ \\
\hline Risk & 11.34 & 0.76 \\
\hline Cost & 12.76 & 0.90 \\
\hline the opportunity & 10.42 & 0.76 \\
\hline Profit & 9.94 & 0.68 \\
\hline Management & 7.74 & 0.71 \\
\hline Political stability & 4.90 & 0.86 \\
\hline
\end{tabular}

In the seventh stage comes to Qi values that are shown in the table below. 
Table 5: Qi values

\begin{tabular}{|c|c||}
\hline Options & Qi \\
\hline Risk & 0.59 \\
\hline Cost & 1.00 \\
\hline the opportunity & 0.53 \\
\hline Profit & 0.32 \\
\hline Management & 0.26 \\
\hline Political stability & 0.41 \\
\hline
\end{tabular}

In the eighth to earn the ranking options based on descending values obtained for $\mathrm{Si}, \mathrm{Ri}$ and Qi. The following table shows the ranking options based on the amount of Si, Ri and Qi.

Table 6: Ranking the options based on the amount of Si, Ri and Qi

\begin{tabular}{||c|c|c|c|c|c|c|}
\hline Options & Risk & Cost & opportunity & Profit & Management & Political stability \\
\hline Rating based on $\mathrm{Si}$ & 5 & 6 & 4 & 3 & 2 & 1 \\
\hline Rating based on Ri & 3 & 5 & 3 & 1 & 2 & 4 \\
\hline Rating based on Qi & 5 & 6 & 4 & 2 & 1 & 3 \\
\hline
\end{tabular}

In the ninth step, we will review and select the best option. In this stage, to examine the conditions you want to discuss options.

The best option (at least Qi) will be achieved under conditions to be established that the following two conditions:

The first condition (reception characteristics):

$$
\begin{aligned}
& Q\left(A^{2}\right)-Q\left(A^{1}\right) \geq D Q \\
& D Q=\frac{1}{m-1}
\end{aligned}
$$

So that :

$\mathrm{A}^{2}$ : The ranking is based on criteria $\mathrm{Q}$, the item is placed in the position or the second position.

$\mathrm{A}^{1}$ : the best option with the least amount for $\mathrm{Q}$

m: Number of options.

The second condition (stability admission decision)

Option $\mathrm{A}^{1}$ should also rated best in the $\mathrm{S}$ or (and) $\mathrm{R}$ is.

1) If one of the above conditions not be established, $A^{1}$ and $A^{2}$ options

2) If the first condition was not established, option $A^{1}$ and $A^{2}, \ldots, A^{m}$.

Am: Option is in position $\mathrm{m}$, the correct relationship.

\section{The first and second test condition}

The first condition is not established. $\quad 0.32-0.26 \geq 0.2 \quad: \times$

The best option Qi

The second condition is not established on the basis of information obtained.

In the table below the results of the rankings.

Table 7: Results Ranking the options

\begin{tabular}{|c|c|}
\hline Options & Rank \\
\hline Risk & 5 \\
\hline Cost & 6 \\
\hline opportunity & 4 \\
\hline Profit & 2 \\
\hline Management & 1 \\
\hline Political stability & 3 \\
\hline
\end{tabular}




\section{DISCUSSION AND CONCLUSION}

What indicators are influencing investment in high-tech industries?

In order to answer this question, researchers conducted a literature review and theoretical framework of research in this area and identify indicators that could be involved in terms of researchers, scientists and experts in investment management and economics in high-tech industries. As the conceptual model showed that effective factors on investment in high-tech industries, including the main criteria for investment (risk, cost, time, profit, management and political stability) and below investment criteria (cultural, governmental, legal, administrative, region $\mathrm{O}$, economic and investment) and any of the following criterion also has the following indicators, which were identified.

What is the importance of effective measures to invest in high-tech industries to one another?

To answer the question of VIKOR fuzzy due to the uncertainty in the responses of experts was used. The importance of effective measures to invest in high-tech industries are as follows:

\section{State the following criteria:}

The following criteria is dedicated following among other criteria, the most important $(0 / 25)$ to itself. Accordingly, it can be stated that the experts one of the following criteria is effective in attracting investment in high-tech industries. In this group are useful indicators or subsets such as: policies and government policies, tariff rates and the relative stability in prices, transparency in the production, transparency of information and statistics and lack of discrimination between the manufacturing.

\section{The following legal and administrative measures:}

The results showed that the second criterion important legal and administrative measures among the criteria for attracting investment in high-tech industries is weighing 0/2167. Based on factors such as stability in the rules and regulations, the administrative system facilitates smooth and flexible rules consistent relationship between science centers, reduce holidays and vacation time, etc., are effective measures to attract investment in high-tech industries.

\section{The following investment criteria:}

The results showed that the third sub-criteria most important investment criteria among the criteria for attracting investment in high-tech industries is weighing 0/20. Accordingly, it can be argued that economic variables, state variables, variables such as legal, cultural variables and regional variables are considered.

4. The economic criteria:

According to the results the following four criteria important measure of economic variables among the criteria for attracting investment in high-tech industries is weighing 1832/0. Accordingly, it can be stated that the following assessment criteria for attracting investment in high-tech industries, bold and undeniable role in economic variables. Therefore, this factor should be considered to be the manager.

5. The following regional standards:

The results showed that the fifth criterion under the criteria important regional variations in the criteria for attracting investment in high-tech industries is weighing 0/0889. In other words, the existence of infrastructure facilities such as roads, railways, airports, etc., are efficient and capable management and a regional strategy to guide investors is an important factor in attracting investment in high-tech industries. 


\section{The following cultural criteria:}

The results showed that the measure cultural variables, sixth and least important criteria among the criteria for attracting investment in high-tech industries 0611/0 weight is a measure cultural variables. The following index is an indicator of cultural criteria less and less impact on attracting investment in high-tech industries.

\section{What are the main criteria for investment in high-tech industries?}

Has been providing review and analysis of data based on the criteria for attracting investment in high-tech industries based on Table 8 .

Table 8: Ranking criteria

\begin{tabular}{|c|c|}
\hline Options & Rank \\
\hline Management & 1 \\
\hline Profit & 2 \\
\hline Political stability & 3 \\
\hline opportunity & 4 \\
\hline Risk & 5 \\
\hline Cost & 6 \\
\hline
\end{tabular}

The above table shows that the management criteria is the most important role in attracting investment in high-tech industries a e0nd are ranked in order of criteria profits, political stability, opportunity, risk and cost.

\section{The research proposal}

According to the results to eliminate barriers and create the enabling environment to attract more investment and attract the presence of the high-tech industry offered the following suggestions in order of importance:

Achievement of objectives requires proper planning and determination of priorities and adopting appropriate strategies and requires a lot of time and effort will be spent. It requires a strong and efficient executive management. Therefore, it seems necessary is a need to do two steps below:

A) Maintain an efficient labor force and entrepreneur

B) attracting and attract qualified personnel and entrepreneur

2. The Director must prevent the occurrence of bureaucracy and administrative bureaucracy and take the pace of consideration of investment applications and licensing to established companies or to enter the high-tech industry. Therefore, it is necessary to put the institutions and organizations and representatives of all departments and agencies and other institutions in the category of office investment with regular practice and its integrated, managed and deployed units.

3. Management should pay more attention to supply manpower available. Cultural barriers must be taken seriously in the labor market. Also extensively in the field of IT illiteracy and lack of advanced industrial base in high-tech industry, a hurdle that must pay to fix it through human resource training and vocational training courses.

4. The success of East Azerbaijan province, according to the special geographical position depends on economic security that need to be addressed through laws and regulations. In addition to secure and reduce investment risk, motivation, and provide a good background in financial and non-financial facilities to attract investment;

5. Demystifying rules and regulations of the review and amend some of the laws and regulations, improve the methods and the rules easy and logical.

6. Funds from the provincial budget and the public, to help build and establish infrastructure facilities and infrastructure. 


\section{REFERENCES}

[1] Asiedu , E. (2002). On the Determinants of Foreign Direct Investment to Developing Countries: Is Africa Different?. World Development, 30(1): 107-119.

[2] Agrawal, J.P. (2008).Determinants of FDI: a survey; Weltwirtschaftliches Archive, Vol. 116, PP. 739 - 773

[3] Aswicahyono,H. (2011). Exports and Job Creation in Indonesia Before and After the Asian Financial Crisis, Arndt-Corden Department of Economics Crawford School of Economics and Government ANU College of Asia and the Pacific

[4] Banga, R. (2009). Impact of Government Policies and Investment Agreements on FDI Inflows. Indian Council for Research on International Economic Relationship (ICRIER), 1: 31-56.

[5] Carbaugh, R. J. (2010), international Economics, ninth edition, Thomson South-western.

[6] Ertuğrul, İ., Karakaşoğlu, N. (2006) "Fuzzy TOPSIS method for academic member selection in engineering faculty", International Joint Conferences on Computer, Information, and Systems Sciences, and Engineering (CIS2E 06), pp.4-14.

[7] Frawsen, G., J. Henrick. (2004). FDI \& Developing Countries, How to Attract Trans National Corporation?. School of Economics and Management, LUND University, No: 36.

[8] Kaufmann, D., Kraay, A., Mastruzzi, M. (2009). Governance Matters VIII, Aggregate and Individual Governance Indicators 1996- 2008, the World Bank, Development Research Group, Macroeconomics and Growth Team, Policy Research Working Paper 4978.

[9] Kahraman, C., Ates, N.Y.; Cevik, S.; Gulbay, M.,Erdogan, S.A. (2007) "Hierarchical VIKOR model for selection among logistics information technologies", Journal of Enterprise Information Management, Vol. 20, No. 2, pp. 143-168

[10]Lutz,S.,Turrini., A. (2006). A general equilibrium model withvertically differentiated industries, skilled labour and trade, Economic Modelling 23. 1 - 19

[11]Feenstra,R.C., Hong., C. (2010). China's Exports and Employment, National Bureau of Economic Research. Chapter pages in book: $(167-199)$

[12] Sitkin, S.B. ,Weingart , L . R .(2006), Determinants of risky decision-making behavior: A test of the mediating role of risk perceptions and propensity, Academy of Management Journal, Vol . 38, No. 6, pp.1573-1582.

[13] Satya P, D. ,(2012). International Trade and Polarization in the Labor Market, Economics: The Open-Access, Open-Assessment E-Journal. Vol. 6

[14] UNCTAD. (2010), World Investment Report; New York and Geneva, United Nation, PP. $91-116$.

[15] Yong, D. (2006) "Plant location selection based on VIKOR ",International Journal of Advanced Manufacturing Technology, Vol. 28,No. (7-8), pp. 839-844.

\section{Article history:}

- $\quad$ Received 17 October 2016

- Accepted 20 May 2017 